\title{
The challenge of using date branch waste as a peat substitute in container nursery production of lettuce (Lactuca sativa L.)
}

\author{
Najla Dhen ${ }^{1}\left[\right.$. Safa ben Abed ${ }^{2} \cdot$ Amin Zouba $^{1} \cdot$ Faouzi Haouala $^{3} \cdot$ Bouthaina AIMohandes Dridi $^{1}$
}

Received: 6 November 2017 / Accepted: 15 September 2018 / Published online: 20 September 2018

(c) The Author(s) 2018

\begin{abstract}
Purpose Peat-based substrates constitute the preferred media in conventional and organic nursery production. Nevertheless, in recent years, there has been a growing interest in environmental impacts associated with peat extraction that has increased with the demand of these non-renewable substrates. The re-use of organic wastes as substrate seems to be good solution to substitute commercial peat. This study evaluates date-palm peat (wastes of date-palm branches base locally known as "Kornef") as an alternative nursery substrate.

Methods The research was conducted in a completely block randomized design with a linear substitution $(0,25,50,75$ and $100 \%$ ) of peat with date-palm waste peat for transplant production of lettuce (Lactuca sativa L.). Different physicochemical parameters (porosity, bulk density, $\mathrm{pH}$, and CEC) of cultivation substrates were measured. The growth parameters (leaves number, leaves area, length, chlorophyll values, fresh and dry weight of seedlings) were evaluated at the end of growth period (when the seedling reached the commercial transplanting size).

Results The results showed that date-palm waste peat is an appropriate media for nursery production, showing similar properties with commercial peat and best plant response with 25 and $50 \%$ substitution.

Conclusions In view of low cost, availability and large area of date-palm cultivation in Tunisia and over the world, it seems that peat can be replaced with substrate of date-palm wastes in the horticulture sector.
\end{abstract}

Keywords Nursery $\cdot$ Kornef $\cdot$ Substrate $\cdot$ Commercial peat $\cdot$ Plantlet growth $\cdot$ Tunisia

\section{Introduction}

Even if greenhouse horticulture occupies a small portion of agricultural land in the world, it has recently expanded considerably in many areas because of its contribution to local or national economy (Massa et al. 2011). Greenhouse production is considered as an effective technique to increase production in many countries (Rostami et al. 2014) due to

Najla Dhen

dhen.najla@yahoo.fr

1 Laboratory of Biochemistry and Environmental Toxicology, High Institute of Agronomy of Chott-Mariem, University of Sousse, 4042 Chott Mariem, Tunisia

2 Laboratory of Dry Land Farming and Oasis Cropping, Arid Regions Institute, Medenine, Tunisia

3 Department of Biology, College of Sciences, Al Imam Mohammad Ibn Saud Islamic University (IMSIU), Riyadh 11623, Saudi Arabia the control of production factors (fertilizing, luminosity, watering) or the nursery substrates quality.

Compared to direct sowing, nursery production is considered as the most consistent method to ensure the proper establishment of a range of commercial horticultural crops with significant economic value (Herrera et al. 2008). One of the most important cultural considerations to produce a successful greenhouse or nursery crop is to identify the appropriate substrate components or pre-formulated substrates (known also as growing mixes or media). In fact, substrates could have direct or indirect effects on transplant growth and development. Traditionally, greenhouse and nursery operations have primarily utilized soilless substrates (Nelson 2003:692). They used organic materials such as peat moss or tree bark blended with other organic or inorganic components such as vermiculite, perlite and sand (Bilderback et al. 2005; Vaughn et al. 2011).

Sphagnum peat-based substrates are the most standard growing media used in container crops. However, their use causes serious environmental issues since they are 
considered as a non-renewable resource and because of the negative impacts on wetland ecosystems associated with peat extraction (Ceglie et al. 2015). In fact, peat mining is increasing throughout the world (Basirat 2011). Its extraction exacerbates climate change because of the release of stable and sequestered carbon into the active carbon cycle (Cleary et al. 2005; Dunn and Freeman 2011; Barrett et al. 2016). This has generated a global movement to develop and utilize sustainable growing media for container-grown plant production.

Awareness of the pollution associated with intensive agriculture forces greenhouse growers to adopt more environment-friendly cultivation methods (Massa et al. 2011). The use of an eco-friendly material (rapidly renewable, locally available with a low cost and able to perform as well as commercial products) as growing medium appears to be a viable alternative crop production system (Abdelrahman et al. 2012; Rostami et al. 2014; Abdelrahman et al. 2016).

For the partial or complete replacement of commercial peat in seedling production, many researchers have studied the use of organic materials derived from primary wastes and transformed wastes of agricultural, agro-industrial, animal manure and municipal solid waste streams (Vaughn et al. 2011; Ceglie et al. 2015; Barrett et al. 2016). The use of switch grass (Panicum virgatum L.), Miscanthus (Altland 2010), rice (Oryza sativa L.) hulls (Locke et al. 2013), poultry manure (Flynn et al. 1995), poultry feather fiber (Evans and Vance 2007), olive mill waste (Raviv et al. 2009), coconut (Cocos nucifera L.) husk fiber (Barrett et al. 2016), corn/ sweatcorn waste, kenaf (Hibiscus cannabinum L.) stem core (Vaughn et al. 2011), municipal solid waste (Herrera et al. 2008) has been reported. Yet, despite this research, few of these materials have been largely adopted in container crops production. Results concerning their potentiality have varied significantly and were not always satisfactory (Carmona et al. 2012). New growing media should be environmentally sustainable, economically feasible and as efficient as those it is replacing.

In recent years, cocopeat (also known as coir dust, coir meal and coir pith), a waste product of the coconut industry, has been adopted as a renewable sphagnum peat substitute (Pickering 1997; Yau and Murphy 2000). Cocopeat has sufficient physical properties similar to peat. It provides plant roots high water content, high total pore space; it has low bulk density, low shrinkage and slow biodegradation (Meena et al. 2017). In contrast to peat, cocopeat is characterized by high re-wetting capacity (Blok and Wever 2008). Given that coco peat is obtained from coconut tree, its industry is geographically limited to America, tropical Africa and Asia (Barrett et al. 2016). Every year, huge amounts of money are spent to import coco peat from other countries (Shirani 2013). On the other hand, palm, which belongs to the same family as coconut, presents high similarity with fiber of coconut fruit hull (Basirat 2011; Ghehsareh et al. 2011) and is considered an important product in Tunisia and Mediterranean basin. These findings suggest that date-palm peat may be considered as a proper substitute for commercial peat in the future.

In the history of humanity, the date-palm (Phoenix dactylifera $\mathrm{L}$.) cultivation and industry have been considered important in day-to-day life. Worldwide, there are approximately 105 million palm trees, an estimated number of over 3675000 tons of residues are discarded annually (Almi et al. 2015) leading to environmental problems (Chandrasekaran and Bahkali 2013; Ghehsareh 2013). Datepalm tree waste includes leaves, branches, stem barks and fronds. They are the most commonly generated waste. They are obtained by seasonal pruning of palm trees which is an essentially agricultural practice and discarded with no valorization. Therefore, from the economic and environmental considerations, the utilization of fronds from the date-palm wastes is a promising project (Almi et al. 2015).

Palm wastes have higher water holding capability than coco peat and can absorb water 8.5 times its dry weight (Chandrasekaran and Bahkali 2013; Shirani 2013). Wastes of date-palm trees seem to be an innovative material in Horticulture industry, to be used as growing media (Ghehsareh 2013) or as an organic fertilizer when used as a biochar (Mahdi et al. 2015). The performance of palm-date wastes peat for plant growth may be leveraged in the production of potted plants but only a few studies have used palm-date wastes as a substitute for peat in potting substrates.

Therefore, the aim of this study was to evaluate the use of fronds palm-date wastes, locally known in Tunisia as "kornef", as an alternative material for peat substitution for the transplant production of lettuce (Lactuca sativa L.) in nursery production.

\section{Materials and methods}

This experiment was performed to identify the effectiveness of date-palm branches wastes to substitute commercial peat and which is the best and most appropriate percentage for producing healthy, strong and homogeneous lettuce plantlets in greenhouse conditions.

\section{Vegetal material and sowing}

Lettuce (Lactuca sativa L.), was chosen as plant model to study the attitude of date-palm branch wastes peat as potting media.

One seed was sowed and grown per cell of foamed polystyrene plug trays with 48 cells of $55 \mathrm{~mL}$ per treatment. The experiment was conducted in an unheated polyethylenecovered greenhouse under natural daylight conditions at the 
Higher Institute of Agronomy of Chott-Mariem (Sousse, Tunisia).

\section{Growing media}

Two growing media were evaluated. Commercial peat (Sphagunum peat) (P) (KLASMANN Potgrond H80) without previous fertilization was used as control and mixed with date-palm fronds wastes peat (K), locally known as "Kornef".

This was prepared by chopping the frond palm-date wastes into small sizes $(2-3 \mathrm{~cm}$ and then to $0.2-4 \mathrm{~mm}$ ). Because of salinity, the material can present phytotoxic levels of sodium and potassium. Thereby several washes in fresh water and a buffering treatment (in which calcium nitrate $\left(\mathrm{CaNO}_{3}\right)$ is added to leach out and remove any excess sodium and potassium from the material). They were kept in $1.5 \mathrm{~m}^{3}$ plastic bags to control the moisture and temperature. Some amounts of animal fertilizer and nitrogen fertilizer $(0.2$ to $0.4 \mathrm{~g} / \mathrm{l})$ were added as a fermentation starter. Air holes were made on the bags to ensure respiration and the moisture was adjusted to 50\%. During 2 months of incubation, these materials were mixed together every week and put into the bags again.

\section{Physico-chemical and chemical characteristics of growing media}

Prepared substrates properties were assessed according to the methods described by Ceglie et al. (2011). In the growing media, $\mathrm{pH}$ ( $\mathrm{ph}$ mètre), electrical conductivity (conductimètre Mettler Toledo), porosity and bulk density were analyzed according to the standard European norms described by Tittarelli et al. (2009).

A 1:5 (V:V) material: water suspension and a filtrate obtained from the diluted materials were used for measurement of $\mathrm{pH}$ and electrical conductivity (EC) using a Jenway combined $\mathrm{pH}$ and Conductivity Meter 3540 (Belda et al. 2016).

\section{Experimental design}

A linear substitution $(0,25,50,75$ and $100 \%)$ of the peat with date-palm fronds wastes peat was considered in a completely randomized plot design, with five treatments and five replications. The treatments were irrigated, according to the environmental conditions, using enough water close to the field capacity to avoid stress in the lettuce seedlings (Ceglie et al. 2015). Two weeks after sowing, a Long Ashton nutrient solution (Hewitt 1966) (1.5 mM $\mathrm{MgSO}_{4}, 7 \mathrm{H}_{2} \mathrm{O} ; 2 \mathrm{mM} \mathrm{K}_{2} \mathrm{SO}_{4} ; 4 \mathrm{mM} \mathrm{CaCl}_{2} .2 \mathrm{H}_{2} \mathrm{O} ; 1.87 \mathrm{Mm}$ $\mathrm{NaH}_{2} \mathrm{PO}_{4} \cdot 2 \mathrm{H}_{2} \mathrm{O} ; 0.13 \mathrm{Mm} \mathrm{Na}_{2} \mathrm{HPO}_{4} \cdot 12 \mathrm{H}_{2} \mathrm{O} ; 4 \mathrm{mM} \mathrm{NaNO}$; $4 \mathrm{mM} \mathrm{NH}_{4} \mathrm{Cl} 0,1388 \mathrm{mM} \mathrm{H}_{3} \mathrm{BO}_{3} ; 0.0208 \mathrm{mM} \mathrm{MnSO}_{4}, 4 \mathrm{H}_{2} 0$;
$2.3 \mu \mathrm{M} \mathrm{ZnSO} \mathrm{Zn}_{4} .7 \mathrm{H}_{2} \mathrm{O} ; 3.3 \mu \mathrm{M} \mathrm{CuSO} \mathrm{Cu}_{4} .5 \mathrm{H}_{2} \mathrm{O} ; 0.2 \mu \mathrm{M}$ $\mathrm{Na}_{2} \mathrm{MoO}_{4} \cdot 2 \mathrm{H}_{2} \mathrm{O} ; 89 \mu \mathrm{M}$ Fe-EDTA) was applied at the same rate for all the treatments once a week.

The substrate treatments were as follows:

S1) Commercial peat as control.

S2) A mixture of Date-palm wastes (25\%) with Commercial peat $(75 \%)$.

S3) A mixture Date-palm wastes (50\%) with Commercial peat $(50 \%)$.

S4) A mixture Date-palm wastes (75\%) with Commercial peat $(25 \%)$.

S5) Date-palm wastes (100\%).

Forty days after sowing, seedlings reached the commercial transplanting size. They were harvested at random from each experimental unit, avoiding those placed next to the edges. In the stems, seedling length (L) was measured from the root collar to the tip of the shoot; Seedlings' numbers of leaves (NL) were counted; also, seedling's leaf area (LA) was determined by leaf area meter.

To determine chlorophyll content, fresh tissue $(1.0 \mathrm{~g})$ was sampled from the youngest fully expanded leaf, extracted with $80 \%$ acetone and read using a UV/visible spectrophotometer 4201/50 at 663 and $645 \mathrm{~nm}$. Acetone was used to correct for any turbidity in the extract before chlorophyll concentrations were calculated as follows (Patel and Thethwar 2015).

Chl a $\left(\mathrm{mg} \mathrm{ml}^{-1}\right)=12.7 \mathrm{~A}_{663}-2.69 \mathrm{~A}_{645}$.

$\mathrm{Chl} \mathrm{b}\left(\mathrm{mg} \mathrm{ml}^{-1}\right)=22.9 \mathrm{~A}_{645}-4.68 \mathrm{~A}_{663}$.

Chla + Chlb $=8.02 \mathrm{~A}_{663}+80.20 \mathrm{~A}_{645}$.

$A_{663}$ and $A_{645}$ represent absorbance values read at 663 and $645 \mathrm{~nm}$ wavelengths, respectively.

Mutual shoot and root's fresh (FW) and dry (DW) $\left(60^{\circ} \mathrm{C}\right.$, 3 days) matter were weighted and their ratio were calculated.

\section{Statistical analysis}

The mean values of experimental data were statistically analyzed by ANOVA to evaluate the significant effect of the nursery substrate factor. Means were compared by Duncan's test at the 5\% level using as data analysis software system SPSS 20.

\section{Results and discussion}

\section{Physico-chemical properties of the growing media}

The main hydro-physical and chemical properties of the different growing media compared to the values established for an "ideal" substrate (Abad et al. 2001; Noguera et al. 2003) are shown in Table 1. The peat substitution with datepalm fronds wastes or "Kornef" generated an increase in the $\mathrm{pH}$ values and in the salinity contents of the mixtures. The 
Table 1 Pysico-chemical properties of the growing media

\begin{tabular}{lllllll}
\hline & $\mathrm{pH}$ & $\mathrm{EC}\left(\mathrm{mS} \mathrm{cm}^{-1}\right)$ & $\mathrm{TPS}(\% \mathrm{vol})$ & $\mathrm{AV}(\% \mathrm{vol})$ & $\mathrm{TAW}(\% \mathrm{vol})$ & $\mathrm{BD}\left(\mathrm{g} \mathrm{cm}^{-3}\right)$ \\
\hline $\begin{array}{l}\text { Acceptable/ } \\
\text { optimum } \\
\text { range }\end{array}$ & $5.3-6.5$ & $<0.5$ & $>85$ & $20-30$ & - & $<0.4$ \\
$S 1$ (control) & $5.67 \mathrm{c}$ & $0.93 \mathrm{~d}$ & $82.50 \mathrm{~b}$ & $22.17 \mathrm{c}$ & $60.33 \mathrm{a}$ & $0.29 \mathrm{a}$ \\
$S 2$ & $5.71 \mathrm{c}$ & $2.41 \mathrm{c}$ & $83.83 \mathrm{ab}$ & $25.83 \mathrm{bc}$ & $58.00 \mathrm{a}$ & $0.212 \mathrm{~b}$ \\
$S 3$ & $6.03 \mathrm{~b}$ & $3.67 \mathrm{~b}$ & $85.00 \mathrm{ab}$ & $29.83 \mathrm{ab}$ & $55.17 \mathrm{a}$ & $0.184 \mathrm{c}$ \\
$S 4$ & $6.06 \mathrm{~b}$ & $4.78 \mathrm{a}$ & $86.83 \mathrm{ab}$ & $31.50 \mathrm{a}$ & $55.33 \mathrm{a}$ & $0.146 \mathrm{~d}$ \\
$S 5$ & $6.46 \mathrm{a}$ & $4.88 \mathrm{a}$ & $88.50 \mathrm{a}$ & $33.67 \mathrm{a}$ & $54.83 \mathrm{a}$ & $0.116 \mathrm{e}$ \\
Significance & $* *$ & $* *$ & $\mathrm{NS}$ & $* *$ & NS & $* *$ \\
\hline
\end{tabular}

$S 1=100 \%$ Peat, $S 2=75 \%$ Peat $+25 \%$ palm-date wastes, $S 3=50 \%$ Peat $+50 \%$ palm-date wastes, $S 4=25 \%$ Peat $+75 \%$ palm-date wastes, $S 5=100 \%$ palm-date wastes

Mean values in columns followed by the same letter are not statistically different according to the Duncan test at $P<0.05$. Statistical significance: $N S$ not significant, $* *$ statistically significant at $P<0.01$, * statistically significant at $P<0.05$

$B D$ bulk density, $E C$ electrical conductivity, $T P S$ total porosity space, $A V$ air volume, $T A W$ Total available water

${ }^{a}$ According to Abad et al. (2001) and Noguera et al. (2003) date-palm fronds wastes-based substrate (S5) manifested the highest $\mathrm{pH}$ and $\mathrm{EC}$ values $(6.46$ and $4.88 \mathrm{mS} / \mathrm{cm}$, respectively). EC values being higher than those suggested as optimum values $\left(\mathrm{EC}<0.5 \mathrm{mS} \mathrm{m}^{-1}\right)$. This fact was also revealed by other researchers when investigating peat substitution using date-palm wastes (Ghehsareh et al. 2012; Rostami et al. 2014; Ceglie et al. 2015; Radhouani et al. 2015).

Analyzing the physical properties, all substrates showed suitable values of the bulk density (BD) $\left(<0.4 \mathrm{~g} \mathrm{~cm}^{-3}\right)$. BD decreased with the incorporation of date-palm wastes giving sufficiently low values so as not to present a problem in transportation or handling. The amount of BD in date-palm wastes peat ( $S 5)$ was minima $(0.116 \mathrm{~g} \mathrm{~cm} 3)$; therefore, root media aeration in this treatment should be better than others. When root media aeration is sufficient, supplying of water and nutrient elements for plants is better (Ghehsareh 2013). Generally, BD and total pore space (TPS) are inversely correlated parameters which could improve plant root growth (Ceglie et al. 2015). This result was in accordance with the values of TPS obtained for different substrates. Higher proportion of date-palm wastes in growing media resulted in significantly greater values of TPS. TPS values of $S 1$ and $S 2$ were slightly under the 'ideal' substrate threshold for the commercial peat substrate but were ideal for other substitutions with date-palm wastes. The replacement of peat moss by $50 \%$ of date-palm fronds wastes $(S 3)$ provided the best air volume (AV) value $(29.83 \%)$ which promotes plant growth. High aeration is important in plug trays with small container [low height $(5-7 \mathrm{~cm})$ ], where the poor drainage after watering is a limiting factor in nursery production (Carmona et al. 2012). Significant differences can be observed in all treatments AV values but were within the acceptable range (20-30\%). Generally, organic wastes have suitable bulk density, porosity and water holding capacity (Borji et al. 2010; Ghehsareh 2013). Whilst, in this study, mixtures with a higher proportion of date-palm wastes showed the lowest amount of total available water $(54.83 \%)$. The highest amounts were observed with the control treatment (S1) (TAW; 60.33\%). The findings of Samiei et al. (2005) support our results when investigating the effectiveness of peat moss and date-palm wastes as substrates for Aglaonema (Aglaonema Commutatum) growing.

A suitable growing media would provide sufficient anchorage to the plant, represent a reservoir for needed water and nutrients, allow oxygen diffusion to the roots and promote gaseous exchange between roots and atmosphere (Bunt 1988: 309; Ghehsareh 2013; Barrett et al. 2016). To be classed as a good growing media, the materials must provide an appropriate balance of air and water based on its physical structure, for healthy root development. Hence, both mixture of date-palm wastes and peat, $S 2$ and $S 3$, seem to have the greatest characteristics compared to peat-based substrate used as control.

\section{Plant response with the different substrates}

A classical method to evaluating novel nursery substrates is to conduct experiments comparing the response of a model plant species grown in this substrate with those grown in standard medium. Plant performance is determined as quantitative measures of plant growth, e.g., growth index and biomass (Barrett et al. 2016).

The effectiveness of peat substitution with different rates of branch date-palm wastes (kornef) peat affected some characteristics of lettuce growth in nursery (Table 2). Interestingly, the peat substitution with $25-50 \%$ of this organic 
Table 2 Lettuce growth attitude on a linear substitution of commercial peat

\begin{tabular}{|c|c|c|c|c|c|c|c|}
\hline & \multirow[t]{2}{*}{$\mathrm{SL}(\mathrm{cm})$} & \multirow[t]{2}{*}{ SNL } & \multirow[t]{2}{*}{ SLA $\left(\mathrm{cm}^{2}\right)$} & \multicolumn{2}{|l|}{ FW (g) } & \multicolumn{2}{|l|}{ DW (g) } \\
\hline & & & & Roots & Shoot & Roots & Shoot \\
\hline \multicolumn{8}{|l|}{ Mixtures } \\
\hline$S 1$ & $8.8 \mathrm{a}$ & $6.8 \mathrm{a}$ & $21.74 \mathrm{a}$ & $0.24 \mathrm{~b}$ & $1.3 \mathrm{ab}$ & $0.075 \mathrm{a}$ & $0.120 \mathrm{ab}$ \\
\hline$S 2$ & $6.6 \mathrm{a}$ & $6.4 \mathrm{a}$ & $19.53 \mathrm{ab}$ & $0.218 b$ & $0.962 b$ & $0.072 \mathrm{a}$ & $0.086 \mathrm{abc}$ \\
\hline$S 3$ & $9.5 \mathrm{a}$ & $7 \mathrm{a}$ & $19.02 \mathrm{ab}$ & $0.618 \mathrm{a}$ & $2.33 \mathrm{a}$ & $0.112 \mathrm{a}$ & $0.148 \mathrm{a}$ \\
\hline$S 4$ & $5.8 \mathrm{a}$ & $6.2 \mathrm{a}$ & $10.23 \mathrm{c}$ & $0.058 \mathrm{~b}$ & $0.53 b$ & $0.022 \mathrm{~b}$ & $0.024 \mathrm{c}$ \\
\hline S5 & $9.6 \mathrm{a}$ & $6.6 \mathrm{a}$ & $13.61 b c$ & $0.052 \mathrm{~b}$ & $0.84 b$ & $0.012 b$ & $0.080 \mathrm{bc}$ \\
\hline Significance & NS & NS & * & * & * & $* *$ & $* *$ \\
\hline
\end{tabular}

$S 1=100 \%$ Peat, $S 2=75 \%$ Peat $+25 \%$ palm-date wastes, $S 3=50 \%$ Peat $+50 \%$ palm-date wastes, $S 4=25 \%$ Peat $+75 \%$ palm-date wastes, $S 5=100 \%$ palm-date wastes

Mean values in columns followed by the same letter are not statistically different according to the Duncan test at $P<0.05$. Statistical significance: $N S$ not significant, $* *$ statistically significant at $P<0.01, *$ statistically significant at $P<0.05$

$S L$ seedling length, $S N L$ seedlings' numbers of leaves, $S L A$ seedling leaf area, $F W$ fresh weight, $D W$ dry weight waste peat stimulated foliar expansion (seedling leaf area, leaves numbers and seedling high) and thereby the accumulation of the fresh and dry matter. Seedlings grown in $S 3$ [(Peat: Kornef) (v:v) (1:1)] revealed significant differences at $5 \%$ level and showed better fresh and dry weight as compared with the commercial peat-based substrate $(S 1)$ and others substrates. However, fresh and dry matters of plantlets grown in $S 4$ and $S 5$ have lower properties.

Seedling leaf area in different substrates had significant difference at 5\% level. Media amended with 25 and $50 \%$ date-palm wastes showed great leaf area values compared to the control. All treatments offer high number of leaves (SNL) that had not any significant difference with peat media used as control. Plantlets grown in commercial peat-based substrate $(S 1), 50 \%$ of date-palm wastes $(S 3)$ and $100 \%$ of date-palm wastes (S5) were longer (seedling length up to $9.6 \mathrm{~cm}$ ) than plants grown in other substrates. These findings can be justified, essentially, by the substrates more favorable aeration that enhances the root oxygen demand and eventually permits more absorption of water and nutrients (Borji et al. 2010). Sufficient properties with a view to low bulk density and high porosity in palm peat media lead to better support of water and nutrient for plant and then better growth.

The highest amount of root and shoot weight in both dry and fresh conditions was related to $50 \%$ peat substitution (S3) with date-palm wastes that had significant difference at $5 \%$ level as compared with other substrates. Roots had more growth in this media's mixture because of its good porosity $(85 \%)$ and so its low bulk density $\left(0.184 \mathrm{~g} \mathrm{~cm}^{-3}\right)$ compared with values established for an ideal substrate. Accordingly, resistance to root motion was minimal in this media. By contrast, the lowest root growth of lettuce plantlets was obtained with $100 \%$ peat substation with date-palm wastes (S5) despite its good physicochemical properties.
These results show that, in general, increasing rates of this organic peat offered excellent growing properties compared to commercial peat but complete substitution produced a decrease in the plant growth (estimated by the root dry and fresh matter in $S 5$ ).

Greatest plantlets biomass (fresh and dry weights) yielded from lettuce grown in such formulations (20-50\% of datepalm wastes) may have been affected by $\mathrm{pH}$ of the materials. The recommended $\mathrm{pH}$ range for lettuce production is 6.0-6.8 (Flynn et al. 1995). The $\mathrm{pH}$ values of all treatments were within the recommended range, averaging 6.03 for $50 \%$ of incorporating this organic waste peat (Kornef) into the commercial peat.

Changes in pigment content are linked to visual symptoms of plant stress and photosynthetic productivity. So that, chlorophyll content has long been relied upon as an indicator of environmental stress impact on plants (Parekh et al. 1990). There are no major significant differences regarding the levels of chlorophyll content of transplants leaves grown in $S 2$ and $S 3$, but are significantly different from other treatments (Table 3). The color intensity of the seedlings (Chla, Chlb, Chla + b) grown in these two ( $S 2$ and $S 3$ ) substrates was higher than in control peat and other mixtures. The

Table 3 The effect of different substrates on chlorophyll content (mg. $\mathrm{g}^{-1}$ fresh matter) of lettuce transplants

\begin{tabular}{lcrrll}
\hline & \multicolumn{1}{l}{$S 1$} & \multicolumn{1}{l}{$S 2$} & \multicolumn{1}{l}{$S 3$} & \multicolumn{1}{l}{$S 4$} & \multicolumn{1}{l}{$S 5$} \\
\hline Chl a & $14.434 \mathrm{~b}$ & $20.115 \mathrm{a}$ & $20.439 \mathrm{a}$ & $8.775 \mathrm{c}$ & $4.458 \mathrm{c}$ \\
Chl b & $4.685 \mathrm{ab}$ & $6.316 \mathrm{a}$ & $8.388 \mathrm{a}$ & $1.148 \mathrm{~b}$ & $3.761 \mathrm{ab}$ \\
Chl $(\mathrm{a}+\mathrm{b})$ & $19.116 \mathrm{~b}$ & $26.426 \mathrm{a}$ & $28.820 \mathrm{a}$ & $9.921 \mathrm{c}$ & $8.217 \mathrm{c}$ \\
\hline
\end{tabular}

$S 1=100 \%$ Peat, $S 2=75 \%$ Peat $+25 \%$ palm-date wastes, $S 3=50 \%$ Peat $+50 \%$ palm-date wastes, $S 4=25 \%$ Peat $+75 \%$ palm-date wastes, $S 5=100 \%$ palm-date wastes, Values followed by the same letter are statistically similar referring to the test of Duncan at $5 \%$ 
chlorophylls can provide a more thorough understanding of physiological responses to growth conditions and plant adaptations to its environment.

During the examination of the morphological responses of lettuce plantlets (Fig. 1) grown in different nursery substrates, satisfactory seedling growth was noted by $S 2$ and $S 3$ substrates. Incorporating date-palm wastes peat to Sphagnum peat-based substrate (control) in a range of 25-50\% significantly improved lettuce plantlets growth.

Date-palm waste properties seem to be enhancer factors for their use as growing medium especially when blended with other substrates. This fact was in accordance with Ghehsareh et al. (2011) and Soltani and Naderi (2016) who found that physiochemical properties of growing media affected the seedling growth. Results of Flynn et al. (1995) on lettuce plants demonstrated that the greatest lettuce biomass yields were from broiler litter composted with peanut hulls mixed with Promix (commercial substrate with a high proportion of peat moss) at a ratio of 3:1 compost: promix and they supposed that it may have been affected by $\mathrm{pH}$ of the materials. The results obtained by Ceglie et al. (2015) revealed that green waste compost (GC) and palm fibre trunk (PF) waste-derived substrates were suitable for their use in peat (SP) substitution. Using a mixture design, authors have reported that a substrate formulation with $20 \% \mathrm{GC}, 39 \% \mathrm{PF}$ and $31 \%$ SP offers the best lettuce, tomato and melon plantlets growth in nursery stage. This formulation includes a high amount of palm fibre waste which confirms our results about date-palm wastes effectiveness in peat substitution. This effectiveness was reported by different authors, such as Ghehsareh (2013), in a study using different mixtures of date-palm wastes and rice hull. He observed that the highest cucumber yield in greenhouse culture and plant height was related to palm waste. To evaluate the possibility of replacing Coco peat as cultivation substrate with date-palm wastes (with different particular size), a study was conducted by Rostami et al. (2014), which indicates that the highest growth and yield of strawberry production belonged to date-palm culture media with $0-5 \mathrm{~mm}$ particular size. Rahbarian and Sardoei (2014) evaluated the substrate effect on the herb Padanus Spp. Some growth indices were greatest on $50 \%$ peat palm $+25 \%$ sand $+25 \%$ perlite and $100 \%$ peat palm substrates, respectively. They reported that palm peat substrates perform as well as peat moss for most plant growth which proves that palm peat can serve as an alternative media for peat.

Although agricultural reuse of plant wastes is well established, only few studies have reported the suitability of datepalm wastes as an effective potting media. However, their use as substrates can involve issues of toxicity (Radhouani et al. 2015). Serious consequences can be caused by direct contact with theses substrates in concentrated form (Christoulaki et al. 2014).Thereby, a mixture of date-palm waste and peat-based substrate seems to be the best formulation to use in nursery production of lettuce. Indeed, fresh wood waste is rarely used as a stand-alone growth medium, and it usually forms a constituent (normally less than 50\%) in mixtures (Christoulaki et al. 2014; Barrett et al. 2016). These findings support our results indicating a peat substitution with a range of $25-50 \%$ of palm-dates wastes or kornef.

\section{Conclusion}

The present study reveals that a supply of 25-50\% date-palm fronds wastes peat in commercial peat may affect commercial substrate properties and improve plant performance for greenhouse cultured lettuce in nursery stage. This encouraging rate is estimated by good seedling growth (high length, number of leaves and biomass) when compared to commercial peat and other substrates. Results demonstrate that datepalm wastes have a great potential to be used in a mixture as a substrate for plant growth in soilless systems. Properties (pH, EC, TPS, BD, etc.) of date-palm wastes peat and its mixture with commercial peat appear to be suitable and were within the optimum range.
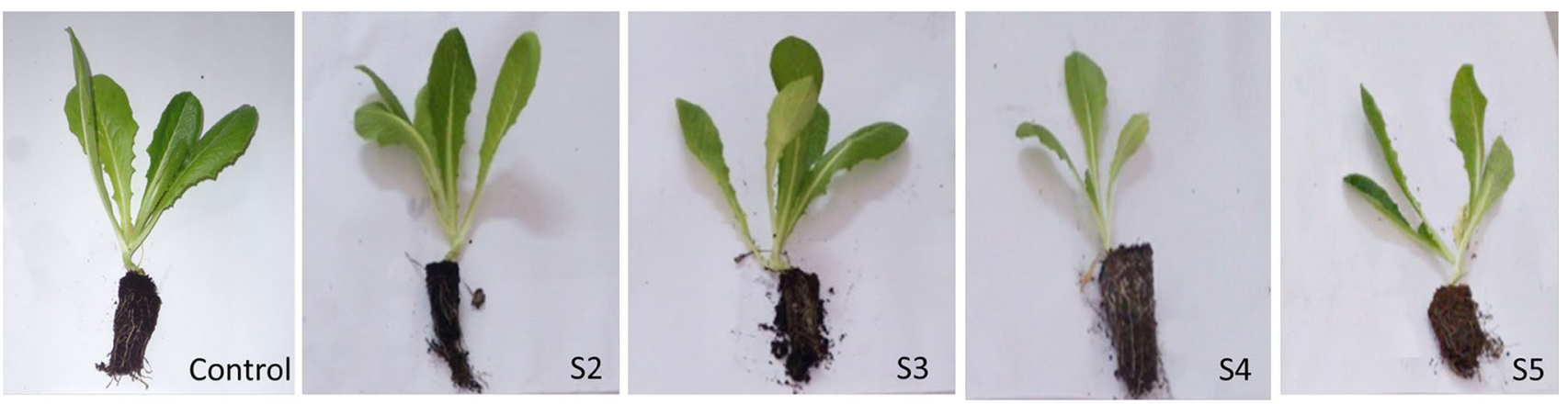

Fig. 1 Morphology of lettuce plantlets grown in different nursery substrates. $S 1=100 \%$ Peat (Control), $S 2=75 \%$ Peat $+25 \%$ palm-date wastes, $S 3=50 \%$ Peat $+50 \%$ palm-date wastes, $S 4=25 \%$ Peat $+75 \%$ palm-date wastes, $S 5=100 \%$ palm-date wastes 
From the obtained results, it can be concluded that datepalm wastes peat material can perform as well as commercial materials it is replacing, giving an environmentally sustainable and commercially viable substrate.

With considering that the continuous use of Sphagnum peat as commercial growing media is being questioned, the use of fiber from date-palm wood waste is a promising project. Switching to an alternative material can be extremely costly and complicated if it does not possess very similar properties to peat. So, a mixture of a new organic media with commercial peat may convince transplant producers.

Future studies should be aimed at improvement and optimizing the proportion of used palm-date waste and an investigation on obtained substrate properties using advanced analysis such as morphology and surface chemistry analysis would be interesting.

Author contribution Conceived and designed the experiments, analyzed the data and wrote the paper: ND and BAD. Performed the experiments: ND and AZ. Contributed materials/analysis tools: ND and SBA. Revision of the manuscript: FH and BAD.

Open Access This article is distributed under the terms of the Creative Commons Attribution 4.0 International License (http://creativeco mmons.org/licenses/by/4.0/), which permits unrestricted use, distribution, and reproduction in any medium, provided you give appropriate credit to the original author(s) and the source, provide a link to the Creative Commons license, and indicate if changes were made.

\section{References}

Abad M, Noguera P, Bures S (2001) National inventory of organic wastes for use as growing media for ornamental potted plant production: case study in Spain. Bioresour Technol 77:197-200. https ://doi.org/10.1016/S0960-8524(00)00152-8

Abdelrahman HM, Ceglie FG, Erriquens FG, Verrastro V, Rivera CM, Tittarelli F (2012) Compost based growing media for organic melon seedlings production. Acta Hort (ISHS) 933:99-106. https ://doi.org/10.17660/ActaHortic.2012.933.10

Abdelrahman HM, Ceglie FG, Awad FA, Tittarelli F (2016) Growth responses of organic tomato seedlings to $\mathrm{N}$ liquid fertilizers and compost-amended growing media. Compost Sci Util 1065657X:2326-2397. https://doi.org/10.1080/1065657X.2016.11835 33

Almi K, Lakel S, Benchabane A, Kriker A (2015) Characterization of date palm wood used as composites reinforcement. Acta PhysPol A 127(4):1072-1074. https://doi.org/10.12693/APhys PolA.127.1072

Altland JA (2010) Use of processed biofuel crops for nursery substrates. J Environ Hortic 28(3):129-134. https://doi.org/10.24266 /0738-2898-28.3.129

Barrett GE, Alexander PD, Robinson JS, Bragg NC (2016) Achieving environmentally sustainable growing media for soilless plant cultivation systems - a review. Sci Hortic 212:220-234. https:// doi.org/10.1016/j.scienta.2016.09.030

Basirat M (2011) Use of palm waste cellulose as a substitute for common growing media in Aglaonema growing. J Ornament Hort Pl 1(1) 1-11. http://jornamental.iaurasht.ac.ir/article_513685.html
Belda RM, Lidon A, Fornes F (2016) Biochars and hydrochars as substrate constituents for soiless growth of myrtle and mastic. Ind Crop Prod 94:132-142. https://doi.org/10.1016/j.indcr op.2016.08.024

Bilderback TE, Warren SL, Owen JR, Albano JP (2005) Healthy substrates need physicals too. Hort Technol 15: 747-751. http://hortt ech.ashspublications.org/content/15/4/747.abstract?sid=9097c dbd-3240-439c-846e-7fa5385dcfe9

Blok C, Wever G (2008) Experience with selected physical methods to characterize the suitability of growing media for plant growth. Acta Hortic 779: 239-249. http://www.actahort.org/books 1779/779_29.htm

Borji H, Ghahsareh AM, Jafarpour M (2010) Effects of the substrate on tomato in soilless culture. Res J Agric Biol Sci 6(6):923-927

Bunt BR (1988) Media mixes for container grown plants: a manual on the preparation and use of growing media for pot plants, 2nd edn. Springer, Netherlands, p 309p

Carmona E, Moreno MT, Avilés M, Ordovás J (2012) Use of grape marc compost as substrate for vegetable seedlings. Sci Hortic 137:69-74. https://doi.org/10.1002/cad.20018

Ceglie FG, Elshafie H, Verrastro V, Tittarelli F (2011) Evaluation of olive pomace and green waste composts as peat substitutes for organic tomato seedling production. Compost Sci Util 19(4):293-300. https://doi.org/10.1080/1065657x.2011.10737 011

Ceglie FG, Bustamante MA, Ben Amara M, Tittarelli F (2015) The challenge of peat substitution in organic seedling production: optimization of growing media formulation through mixture design and response surface analysis. PLoS One 10(6):e0128600. https ://doi.org/10.1371/journal.pone.0128600

Chandrasekaran M, Bahkali AH (2013) Valorization of date palm (Phoenix dactylifera) fruit processing by-products and wastes using bioprocess technology-review. Saudi J Biol Sci 20:105120. https://doi.org/10.1016/j.sjbs.2012.12.004

Christoulaki M, Gouma S, Manios T, Tzortzakis N (2014) Deployment of sawdust as substrate medium in hydroponically grown lettuce. J Plant Nutr 37(8):1304-1315. https://doi.org/10.1080/01904 167.2014.881870

Cleary J, Roulet NT, Moore TR (2005) Greenhouse gas emissions from Canadian peat extraction, 1990-2000: a life cycle analysis. J Hum Environ 34(6):456-461. https://doi. org/10.1579/0044-7447-34.6.456

Dunn C, Freeman C (2011) Peatlands: our greatest source of carbon credits. Carbon Manag 2(3):289-301. https://doi.org/10.4155/ cmt.11.23

Evans MR and Vance L (2007) Physical properties of processed poultry feather fiber-containing greenhouse root substrates. Horttechnology 17 (3): 201-304. http://horttech.ashspublications.org/conte nt/17/3/301.full?sid=e0b6b87d-b1a3-44ad-bec6-e14e11cee390

Flynn RP, Wood CW, Guertal EA (1995) Lettuce response to composted broiler litter as a potting substrate component. J Am Soc Hortic Sci 120(6):964-970

Ghehsareh AM (2013) Effect of date palm wastes and rice hull mixed with soil on growth and yield of cucumber in greenhouse culture. Int J Recycl Org Waste Agricult. 2-17. https://doi. org/10.1186/2251-7715-2-17

Ghehsareh AM, Borji H, Jafarpour M (2011) Effect of some culture substrates (date-palm peat, cocopeat and perlite) on some growing indices and nutrient elements uptake in greenhouse. Afr J Microbiol Res 5(12):1437-1442. https://doi.org/10.5897/AJMR10.786

Ghehsareh AM, Hematian M, Kalbasi K (2012) Comparison of datepalm wastes and perlite as culture substrates on growing indices in greenhouse cucumber. Int J Recycl Org Waste Agricult 1:5. https ://doi.org/10.1186/2251-7715-1-5

Herrera F, Castillo JE, Chica AF, López Bellido L (2008) Use of municipal solid waste compost (MSWC) as a growing medium 
in the nursery production of tomato plants. Bioresour Technol 99:287-296. https://doi.org/10.1016/j.biortech.2006.12.042

Hewitt EJ (1966) Sand and water culture methods used in the study of plant nutrition, 2nd revised ed. Commonwealth Agricultural Bureau, Farnham Royal, Bucks, pp 547

Locke J, Altland J and Ford C (2013) Gasified rice hull biochar affects nutrition and growth of horticultural crops in container substrates. J Environ Hortic. 31(4): 195-202. http://hrijournal.org/ doi/full/10.24266/0738-2898.31.4.195

Mahdi Z, El Hanandeh A and Yu QJ (2015) Date palm (Phoenix Dactylifera $L$.) seed characterization for biochar preparation. In: The 6th international conference on engineering, project, and production management (EPPM), 2-4 September 2015, Gold Coast

Massa D, Incrocci L, Maggini R, Bibbiani C, Carmassi G, Malorgio F, Pardossi A (2011) Simulation of crop water and mineral relations in greenhouse soilless culture. Environ Model Softw 26:711-722. https://doi.org/10.1016/j.envsoft.2011.01.004

Meena AK, Garhwal OP, Mahawar AK, Singh SP (2017) Effect of different growing media on seedling growth parameters and economics of papaya (Carica papaya L) cv. Pusa delicious. Int J Curr Microbiol Appl Sci 6(6):2964-2972. https://doi.org/10.20546/ ijcmas.2017.606.353

Nelson PV (2003) Greenhouse operation and management, 6th edn. Department of Horticultural Science, North Carolina State University, Raleigh, p 692

Noguera P, Abad M, Puchades R, Maquieira A, Noguera V (2003) Influence of particle size on physical and chemical properties of coconut coir dust as a container medium. Commun Soil Sci Plant Anal 34:593-605. https://doi.org/10.1081/CSS-120017842

Parekh D, Puranik RM and Srivastava HS (1990) Inhibition of chlorophyll biosynthesis by cadmium in greening maize leaf segments. Biochem Physiol Pflanz 186: 239-242. https://www.cabdirect.org/ cabdirect/abstract/19910742075

Patel K and LK Thethwar (2015) Study of plants for their chlorophyll content, phenolic content and antioxidant properties. Baharat J Scien Technol 1(1): 65-67. http://www.cvruresearch.org

Pickering JS (1997) An alternative to peat. The Garden 122:428-429

Radhouani C, Leonardi, B, Lechaieb L, Ben Yahya A, Ferchichi A (2015) Assessment of the potential of two local composts for seeds germination and vegetable production. J New Sci 20(1):780-787
Rahbarian P, Sardoei AS (2014) Effect of different media on growth, sucker and chlorophyll of padanus spp in under system mist. Intl J Farm Alli Sci 3(3):285-288

Raviv M, Medina S, Krassnovsky A, Laor Y, Aviani I (2009) Composting olive mill waste and assessment of its horticultural value. Acta Hortic 819: 353-359. http://www.actahort.org/books/819/819_42. htm

Rostami Z, Ghahsare AM, Kavoos B (2014) Date Palm waste application as culture media for strawberry and its impact on some growth indices and yield components. Agri Communi 2(3):15-21. https://www.cabdirect.org/cabdirect/abstract/20143287046

Samiei L, Halighi KA, Kafi M, Samavat S, Arghavani M (2005) An investigation of substitution of peat moss with palm tree celluloid wastes in growing aglaonema (Aglaonema Commutatum Cv. Silver Queen). Iran J Agric Sci 36(2):503-510

Shirani M (2013) Use of date-palm wastes as a substrate on tomato yield and number. Biol J Armenia 1(65):63-67

Soltani M, Naderi D (2016) Yield compounds and nutrient elements of carnation (Dianthus caryophyllus L.) under different growing media. Open J Ecol 6:184-191. https://doi.org/10.4236/ oje.2016.64019

Tittarelli F, Rea E, Verrastro V, Pascual JA, Canali S, Ceglie FG (2009) Compost-based nursery substrates: effect of peat substitution on organic melon seedlings. Compost Sci Util 17(4):220-228. https ://doi.org/10.1080/1065657X.2009.10702427

Vaughn SF, Deppe NA, Palmquist DE, Berhow MA (2011) Extracted sweet corn tassels as a renewable alternative to peat in greenhouse substrates. Ind Crops Prod 33:514-517. https://doi.org/10.1016/j. indcrop.2010.10.034

Yau PY and Murphy RJ (2000) Biodegraded cocopeat as a horticultural substrate. Acta Hortic 517:275-278. http://www.actahort. org/books/517/517_33.htm

Publisher's Note Springer Nature remains neutral with regard to jurisdictional claims in published maps and institutional affiliations. 